\title{
Creating an integrated information system for the analysis of mammalian fauna in the Russian Federation and the preliminary results of this information system
}

\author{
Andrey A. Lissovsky, Boris I. Sheftel, Valery V. Stakheev, Oleg A. Ermakov, \\ Dmitri G. Smirnov, Dmitri M. Glazov, Dmitri P. Strelnikov, Alexander V. \\ Ekonomov, Sergey V. Titov, Ekaterina V. Obolenskaya, Yuri A. Kozlov \& \\ Alexander P. Saveljev*
}

\begin{abstract}
The current capacity for the purposeful study of the mammalian fauna of Russia using public databases is discussed. A list of species of Russian fauna compiled under united principles is lacking and the lists of species published in different departments are inconsistent. Systems that can monitor changes in the qualitative or quantitative composition of the fauna are not yet sufficiently refined. The systematization of previously accumulated faunal data requires the involvement of qualified taxonomists. Nevertheless, initial work on the "Mammals of Russia" database, which currently contains 16512 records on 235 species of mammals, has allowed us to positively assess the prospects for further ordering of faunal information within the country.

How to cite this article: Lissovsky A.A., Sheftel B.I., Stakheev V.V., Ermakov O.A., Smirnov D.G., Glazov D.M., Strelnikov D.P., Ekonomov A.V., Titov S.V., Obolenskaya E.V., Kozlov Yu.A., Saveljev A.P. 2018. Creating an integrated information system for the analysis of mammalian fauna in the Russian Federation and the preliminary results of this information system // Russian J. Theriol. Vol.17. No.2. P.85-90. doi: 10.15298/rusjtheriol.17.2.04
\end{abstract}

KEY WORDS: mammals, Russia, fauna, information system.

AndreyA.Lissovsky[andlis@zmmu.msu.ru], EkaterinaV. Obolenskaya [obolenskaya@zmmu.msu.ru], Zoological Museum of Moscow State University, Bolshaya Nikitskaya 6, Moscow 125009, Russia; Valery V. Stakheev [stvaleriy@yandex.ru], Federal Research Center The Southern Scientific Centre of the RAS, Chehova 41, Rostov-onDon 344006, Russia; Boris I. Sheftel [borissheftel@yahoo.com],Dmitri M. Glazov [dglazov@yandex.ru], Severtsov Institute of Ecology and Evolution RAS, Leninskiy pr. 33, Moscow 119071, Russia; Oleg A. Ermakov [oaermakov@list.ru], SergeyV.Titov[svtitov@yandex.ru],Dmitri G. Smirnov[eptesicus@mail.ru], Penza State University, Krasnaya 40, Penza 440026, Russia; Dmitri P. Strelnikov [dmitrijs1987@mail.ru], AlexanderV. Ekonomov[aconom86@mail.ru], Yuri A. Kozlov[kozlow.y@yandex.ru], Alexander P. Saveljev [saveljev.vniioz@mail.ru], Russian Research Institute of Game Management and Fur Farming, Preobrazhenskaya str. 79, Kirov 610000, Russia.

\section{Создание интегрированной информационной системы анализа фауны и ресурсов млекопитающих России и первые шаги её реализации}

\section{А.А. Лисовский, Б.И. Шефтель, В.В. Стахеев, О.А. Ермаков, Д.Г. Смирнов, Д.М. Глазов, Д.П. Стрельников, А.В. Экономов, С.В. Титов, Е.В. Оболенская, Ю.А. Козлов, А.П. Савельев*}

РЕЗЮМЕ. Обсуждается современная готовность целенаправленного изучения фауны млекопитающих России при помощи разработки публичной базы данных. Отмечается отсутствие «официального» списка фауны, составленного по единым принципам и неполная согласованность в списках видов, публикуемых в разных ведомствах. Системы мониторинга, позволяющие отслеживать изменение качественного или количественного состава фауны, пока также не налажены. Систематизация накопленных ранее фаунистических данных требует привлечения квалифицированных систематиков. Тем не менее, первые месяцы работы базы данных «Млекопитающие России», за которые накоплены 16512 записей по 235 видам млекопитающих, позволяют позитивно оценить перспективы дальнейшего упорядочивания фаунистической информации в пределах страны.

КЛЮЧЕВЫЕ СЛОВА: мЛекопитающие, Россия, фауна, информационная система.

* corresponding author 


\section{Introduction}

The modern pace of life dictates terms in all branches of knowledge and most of the World's states. The increase in the rate of accumulation of knowledge is due to the introduction of various automation technologies for information processing. At the same time, the feeling of increasing tempo in many people is associated with the asynchronous implementation of these technologies in different spheres of human activity. For zoologists and botanists this speed of life, which runs faster and faster, is very appreciable. One of the reasons for this is that the development of the extractive industry and various ways of transferring energy, construction, reconstruction, and resettlement of people in a modern "ecologically oriented" society require the constant participation of qualified expert biologists in the evaluation of the possible damage to wildlife resources. Since the automation of information processing in field biology is far behind that of advanced construction technologies, there is an undeniable imbalance: demands far exceed the existing ability to respond. As a result, low-skilled "experts" become involved in such work, and the resulting information is published in specialized papers scattered among hundreds of little known scientific journals and proceedings. As a result, everyone suffers - it can take a long time to find the relevant information for specialists, companies cannot verify the reliability of expert information, and the state loses natural resources.

This situation is especially acute for those who study mammals, since the subjects of their studies occupy high levels within the pyramid of numbers, and thus the distribution and abundance of species can vary quickly and without one-step relations to environmental change. Tracing of distributional and population changes is a task for an information system (database) that has been lacking in Russia until 2018.

The main aim of this study was to analyse the possible problems and perspectives in the development of such an information system in Russia.

\section{Material and methods}

We analysed official documents devoted to hunting species of mammals (Federal Law 209-FZ, 2009, Federal Law 166-FZ, 2004; as well as other documents at the federal, regional and international level), epizootic services (Federal Law 52-FZ, 1999 and several other documents at the federal level) and Red Data Books (RDBs) at the State and regional levels (Ilyashenko et al., 2018, etc.; http://oopt.aari.ru/rbdata) and compared them to a recent checklist of Russian mammalian fauna (Pavlinov \& Lissovsky, 2012). We also analysed the dynamics of data accumulation in the database "Mammals of Russia" (http://rusmam.ru) during the first 9 months after its creation, taking into account several simple parameters: number of records, number of recorded species, dates and geography of records, and category of users (professional/amateur). Simultaneously we traced all public discussion in a subsidiary Facebook group "Mammals of Russia": https://www. facebook.com/groups/rusmammals/. "Mammals of Russia" was advertised in the mass media, but has not been advertised in the professional community to date.

The database "Mammals of Russia" collects the following kinds of information. Obligatory data: species name, locality description and geographic coordinates, coordinates affixment precision (in metres), date and author of animal observation, data source, and type of information used for species identification. Facultative data, such as information on species abundance, photos and literature sources can be added to each record. Every record is moderated by experts before it enters the database.

\section{Results}

The document analysis revealed discordance between the information obtained by different governmental agencies and the lack of available checklists of Russian mammalian fauna. The only checklist of Russian fauna (Pavlinov \& Lissovsky, 2012) contains detailed information on the taxonomic position of the majority of mammalian taxa, however the taxonomic scheme adopted means it is unsuitable for use by zoologists without a specialist phylogenetic underground. Some taxa have no "species" rank (marked as semispecies, superspecies etc.). It is very useful for understanding phylogenetic patterns, but says nothing about the various operative units that are necessary for official documentation. Besides, this checklist contains a number of species that have not been recorded in Russia for dozens or even hundreds of years, and thus it cannot be used as a basis for a modern list of Russian mammalian species.

We modified the species list of Pavlinov \& Lissovsky (2012) by removing species that have not been recorded in Russia since 1950; we also updated the list to provide a "classic view" in which species taxonomic rank is obligatory for usability reasons. The total list contains 332 species from seven orders, 44 families and 145 genera. The list is available online at http:// rusmam.ru/mammalslist. Additionally we compiled a list of game mammals in Russia; paradoxically a complete list was previously lacking, since some mammals were recorded in documents as composite groups (see below). The list of hunting mammals contains 89 species (Saveljev et al., in press) from five orders: four eulipotyphlans (moles), five lagomorphs (wild rabbit and hares), 18 rodents, 38 carnivores including pinnipeds, 17 artiodactyles and seven cetaceans.

Various official documents including Red Data Books often use outdated Latin (scientific) names (such as Neomys schelkovnikovi in the RDBs of the North Caucasian republics of Chechnya (Regulation, 2007), Ingushetiya (Regulation, 2006) and Kabardino-Balkaria (Regulation, 2004), and Vespertilio superans in the 
RDB of Primorskiy Territory(Regulation, 2002)), specific taxonomic ideas that are not popular in modern taxonomy (e.g. Lemmus flavescens in the RDB of Kamchatka Territory (Regulation, 2010)), or common names for mammals, like "mink" or "polecat" for hunting animals (see: Federal Law 209-FZ, 2009), which indicates that attitudes to some economically important animals have not been reconsidered for a long time, during which population status may have changed. Red Data Books can include species that were recorded once a hundred years ago and have not been recorded since in the territories in which they are now protected (e.g. the dhole Cuon alpinus listed in 10 Russian regional RDBs, see Makenov, 2018).

The absence of electronic databases in most Russian scientific museums notably hampers the development of faunistic studies. People brain can hardly keep all information on modern large collections. Since the possibility of successfully retaining such large amounts of information is disputable, an electronic database would increase the efficiency of such expertise notably.

Undoubtedly, a huge amount of faunistic information has been accumulated by zoologists and hunters to date. Most of this information is scattered in poorly known paper collections, regional journals, books of abstracts and various reports. This information will be fully available only after digitizing it in an integrated information system like "Mammals of Russia". Unfortunately this information was collected under different taxonomic concepts, so the addition of such data to modern databases needs careful taxonomic expertise. At the same time the naturalist and wildlife photographer communities are ready to transmit data to the scientific community right now. The main obstacle they encounter is a lack of species' identification guides and popular description of species' ecology prepared by professionals. Thus, both faunistic publications and data from naturalists require the moderation of species identification by experts.

There is no established system of wildlife monitoring in Russia. Several governmental services partially carry out this job, but each service has its own defects. The hunting service accumulates data from winter route counts of several species of hunting mammals. However the qualifications of the hunters involved in species identification are never checked; besides, the abundance of animals in such counts is positively correlated with the number of future licenses. Thus such monitoring can lead to biased results. The most consistent monitoring of hunting species probably comes from the Department of Hunting Resource Studies of the Russian Research Institute of Game Management and Fur Farming (VNIIOZ), which conducts an all-Russian poll of hunters twice a year. An advantage of this method is the supposed qualification of hunters that have participated in the poll for many years. The epidemiological service takes samples from nature for the control of focal zoonoses annually; these samples include small mammals. However not all staff members are qualified to identify species of mammals, so they may be reported as "shrews" or "mice" for example. Small mammal monitoring takes place in some Nature Reserves, but there is no central repository to which to submit the results of such monitoring. Furthermore, the sites of any kind of monitoring are distributed very irregularly.

Of course, as a large country (about 17125100 $\mathrm{km}^{2}$ ) Russia has specific problems. Many parts of the country are not accessible by public transportation; and the number of mammalogists (485 persons were registered at the last all-Russian Theriological Congress in 2016) is insufficient to cover the territory with a regular monitoring network. Nevertheless, during its 9 months of existence, the information system "Mammals of Russia" has accumulated a large amount of information, with realistic outlines of some distribution ranges, especially of hunting mammals, having been obtained. There are 16512 records in the system, 1901 of them supported by photos. The records contain information on 235 species (71\% of fauna): Eulipotyphla - 684 records; Chiroptera - 2220; Carnivora — 5286; Artiodactyla - 2013; Cetacea - 24; Lagomorpha 1163; Rodentia - 5122. The dynamics of data arrival is shown in Fig. 1. The geographical distribution of data is very irregular. The top five positions are occupied by regions with high levels of activity by this paper's coauthors: Rostov Region - 2108 records; Voronezh Region - 1559; Penza Region — 856; Kirov Region 785; Bryansk Region — 751. The bottom five are as follows: Khakassia Republic - 10; Kemerovo Region - 9; Magadan Region - 3; Tomsk Region - 3; Chechnya Republic - 1. The data have been entered into database by 212 users: 182 naturalists and 30 professional zoologists. At the same time, discussions have taken place within a Facebook group, to which 642 participants belong; their professional affiliations are not available in the group.

\section{Discussion}

The role of public databases in faunistic, ecological and conservation studies is obvious (Kobori et al., 2016). Since the second half of the 20th century, the volume of available data has exceeded the capacity for processing by the efforts of one or two people. Data are replenished constantly, and the number of sources is growing. Amateur sources add more information than professional publications, and include reports made by tourists, wildlife photographers photos, hunter's trophies etc. A database can store all of this information in the same data scheme, and each record can be critically examined by an expert. A problem with faunistic studies is that the results of the expert's work are not retained for subsequent researchers in full. The volume of available data does not allow the publication of critical notes about each record that may have raised the expert's doubts. This means that many "known" records do not appear on maps, and thus the process of 


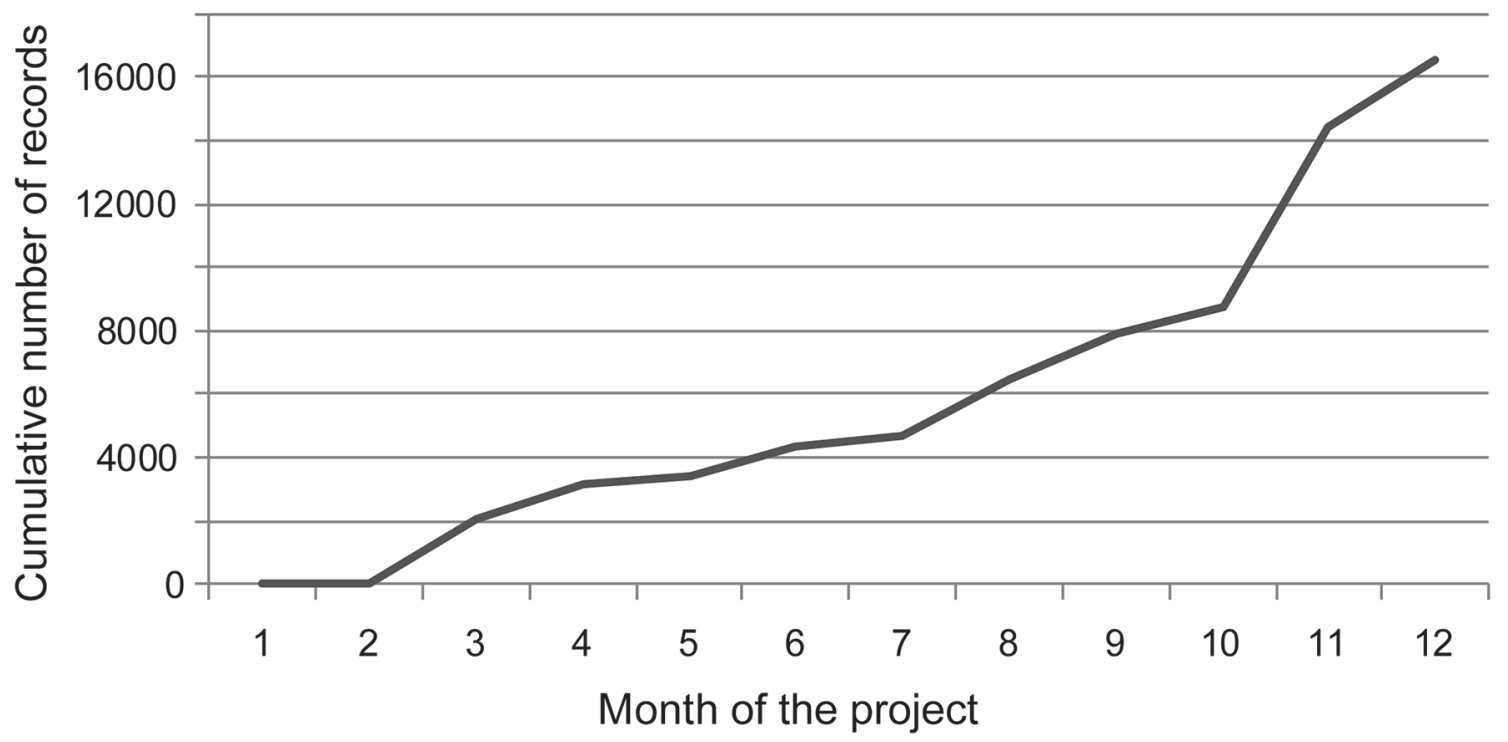

Fig. 1. Dynamics of the number of faunistic records, published by the website "Mammals of Russia" from December 2017 to September 2018.

looking for information has to start from the beginning. Databases can accumulate expert opinion too. Thus databases remove informational obstacles.

A related benefit: database can generate dot maps directly from its records. Thus each dot on the map can bear interactive information, which is useful for users. Examples can be viewed at http://rusmam.ru/map/ (Fig. 2). Thus databases can streamline the efforts of investigators, removing the need for repeated searches for the same information.

Analysis of the parameters presented in the Results section leads us to conclude that neither the taxonomic composition of the data, nor the geographic distribution or data arrival dynamics reflect natural processes such as the taxonomic structure of the fauna or the geographic distribution of zoologists or studies. It is likely that the parameters values illustrate the very first step of data accumulation, when random factors drive the process of accumulation. So, the parameters studied should be reanalysed at a later date. In the case of our digital resource, it is possible to publish ongoing statistics.

The very first experience of using "Mammals of Russia" seems promising. The existing data flow allows every record to be moderated by experts, without long delays. The wildlife interested community seems interested, and the data originating from it (photos with geographic coordinates) are good enough for identification in the majority of cases. The zoologists involved in the project are providing a stable data flow. Major sources of information such as collections of the biggest zoological museums, published faunistic information and the monitoring network of Nature Reserves have not yet been included since bigger information pools need more time for entry into the database. Therefore we have grounds to hope for increasing data flow in the next few years.
Other countries have had a positive experience of faunistic database management. Hundreds of amateur Internet resources have helped accumulate faunistic data all over the world. The vast majority of them are devoted to birds, as the most recognizable objects among wildlife, however other databases collect data on fish (https://www.fishbase.de), plants (http://www. plantarium.ru), etc. There are amateur resources that cover all kinds of fauna within a single state, with a data coverage density exceeding that of professional publications (e.g. http://www.birds.kz). There are also amateur resources with active involvement of professionals (e.g. http://www.birdsmoscow.net.ru). Some professional resources in Europe actively use amateur data, and are dedicated to mammals (e.g. https://www. verspreidingsatlas.nl/zoogdieren; http://www.mammalsin-ireland.ie). The majority of amateur databases have an acute problem with data verification. The undefined quality of species identification causes difficulties for subsequent scientific data use. On this basis, "Mammals of Russia" occupies an advantageous position all records are moderated by qualified experts before they become available for users. Every record gets a score (1-3), indicating the possible quality of identification. This score allows users to filter records for subsequent scientific purposes.

European countries have started the second round of mapping of birds, reptiles and mammals; for mammals there is a Pan-European project called EMMA2 (https://www.european-mammals.org/). The majority of countries use national databases (ND) to manage fauna or mammal populations (https://www.europeanmammals.org/public-documents/send/2-emma2-publicdocuments/50-final-report-of-dg-meeting-prague-april2018). Several countries, including Great Britain, Ireland, the Czech Republic, Denmark, The Netherlands, 


\section{Карта млекопитающих в России}

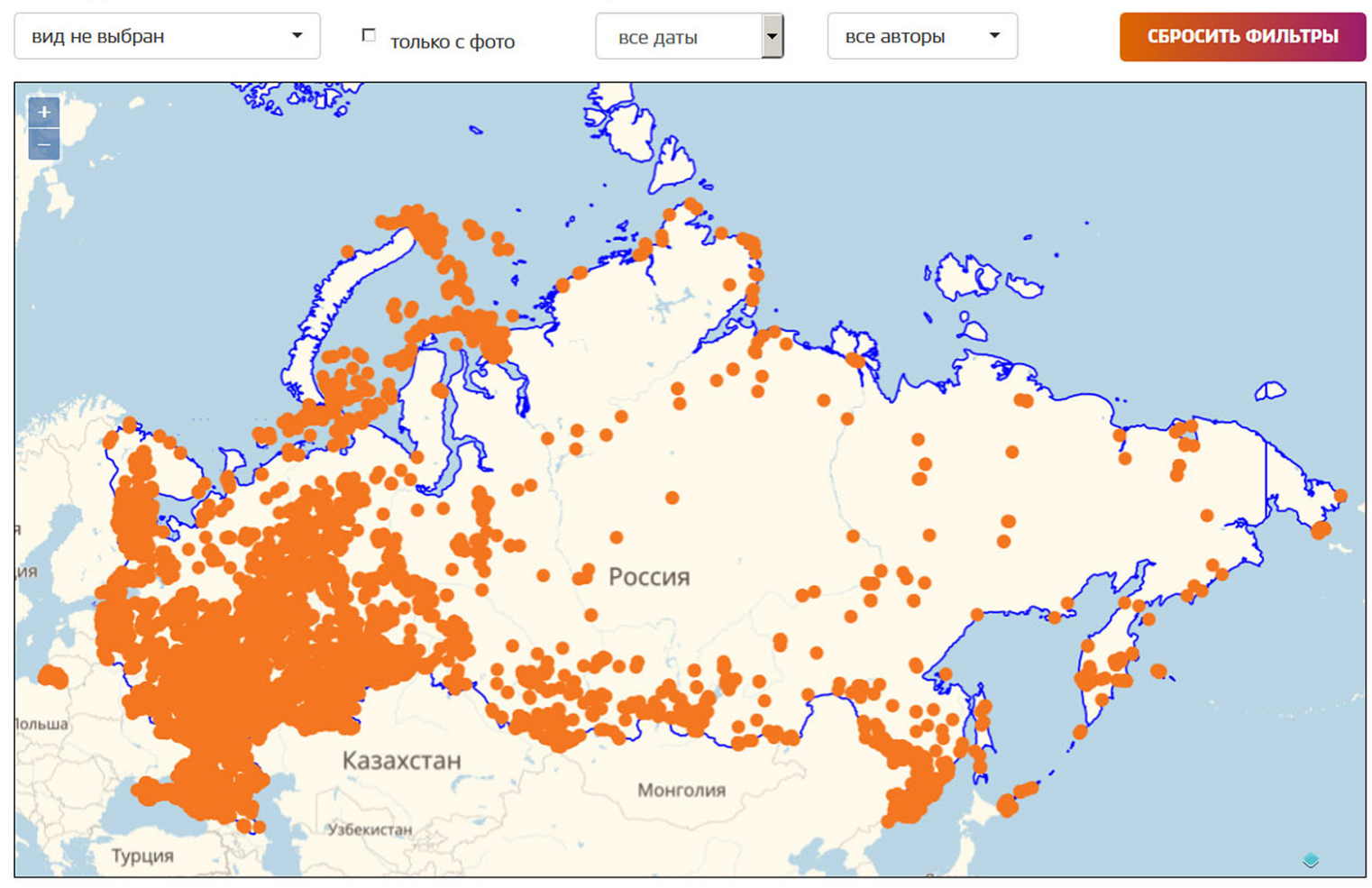

Fig. 2. Mapping interface of the website "Mammals of Russia". The state on the end of September, 2018.

Italy, France and Spain, have well-developed ND and are ready to publish their National Atlases or have published them already (Andìra et al., 1995-2007; Lysaght \& Marnell, 2016; Savoure-Soubelet et al., 2018). European Atlases are based on a $50 \mathrm{~km}$ square grid, each cell of which is filled with information on species presence/absence (Mitchell-Jones et al., 1999).

"Mammals of Russia" is completely compatible with EMMA2 in terms of information structure (see http:// rusmam.ru/atlas/). Nevertheless the task of filling all $50 \times 50 \mathrm{~km}$ cells of even only European Russia with species presence information will be a challenge: 1659 cells need to be filled with information on 179 species that inhabit the European part of Russia covered by the EMMA2 project. This will require more than the efforts of existing specialists. In the case of Russia, spatial extrapolation is a necessary tool for predicting species distribution. The peculiarities of using the database for the automation of species distribution modelling is a separate issue.

In summary, the first phase in the development of the "Mammals of Russia" database has yielded positive results. The database structure allows the collection of data compatible with the EMMA2 project. The data are suitable for further scientific analysis due to professional moderation. Streamlining of the data flow will require the creation of links with governmental monitoring systems. The latter task will require the creation of species lists that are available for official structures. Intensive involvement of naturalists will be possible after the publication of popular identification guides, allowing visual species identification.

Acknowledgments. This study was supported by the Russian Science Foundation (18-14-00093).

\section{References}

Anderra M. et al. 1995-2007. Atlas of the Mammals of the Czech Republic. Praha: Národní Muzeum. Vols.1-5.

Federal Law 52-FZ. 1999. Federal Law “On Public Sanitary Well-Being". Published on March 30, 1999. Available on-line at http://www.consultant.ru/document/ cons_doc_LAW_22481/.

Federal Law 166-FZ. 2004. Federal Law "On Fisheries and the Conservation of Aquatic Biological Resources". Pub- 
lished on December 20, 2004. Available online at http:// www.consultant.ru/cons/cgi/online.cgi?req $=\mathrm{doc} \&$ base $=$ LAW\&n=278889\&nd=9A1C8C670A5ACA7BF87448F9999 4E50C\&from $=301250-8 \# 09234578942576197$.

Federal Law 209-FZ. 2009. Federal Law "On the Hunting and the Conservation of Hunting Resources and on Amendments to Certain Legislative Acts of the Russian Federation". Published on July 24, 2009. Available online at http://www.consultant.ru/document/cons_doc_ LAW 89923/.

Ilyashenko V.Yu., Shatalkin A.I., Kuvaev A.V., Komendatov A.Yu., Britaev T.A., Kosyan A.R., Pavlov D.S., Shilin NI, Ananieva N.B., Tuniev B.S., Semenov D.V., Syroechkovsky E.E., Morozov V.V., Mischenko A.L., Rozhnov V.V. \& Poyarkov A.D. 2018. [Rare and threatened animals of Russia. Materials to the Red Data Book of the Russian Federation]. Moscow: KMK Sci. Press. 112 p. [In Russian]

Kobori H., Dickinson J.L., Washitani I., Sakurai R., Amano T., Komatsu N., Kitamura W., Takagawa S., Koyama K., Ogawara T. \& Miller-Rushing A.J. 2016. Citizen science: a new approach to advance ecology, education, and conservation // Ecological Research. Vol.31. P.1-19.

Lysaght L. \& Marnell F. (eds.). 2016. Atlas of Mammals in Ireland 2010-2015. Waterford: National Biodiversity Data Centre. 207 p.

Makenov M. 2018. Extinct or extant? A review of dhole (Cuon alpinus Pallas, 1811) distribution in the former USSR and modern Russia // Mammal Research. Vol.63. No.1. P.1-9.

Mitchell-Jones A.J., Amori G., Bogdanowicz W., Krystufek B., Reijnders P.J.H., Spitzenberger F., Stubbe C., Thissen J.B.M., Vohralík V. \& Zima J. 1999. The Atlas of European Mammals. London: T \& AD Poyser Ltd. 496 p.

Pavlinov I.Ya. \& Lissovsky A.A. (eds.). 2012. The Mammals of Russia: A Taxonomic and Geographic Reference. Moscow: KMK Sci. Press. 604 p. [in Russian and English]
Regulation. 2002. Regulation of governor of Primorskiy Territory from 14.05.2002 №272. On approval of the list of flora objects and the list of fauna objects listed in the Red Book of Primorskiy Territory. Available online at http://oopt.aari.ru/rbdata/77/anim.

Regulation. 2004. Regulation of government of KabardinoBalkaria Republic from 28.05.2004 №170-ПП. On approval of the list of flora and fauna objects listed in the Red Book of the Kabardino-Balkaria Republic. Available online at http://oopt.aari.ru/rbdata/1755/anim.

Regulation. 2006. Regulation of government of Ingushetiya Republic from 28.11.2006 №173. On approval of the list of rare and endangered objects of flora and fauna for listing in the Red Book. Available online at http:// oopt.aari.ru/rbdata/1754/anim.

Regulation. 2007. Regulation of government of Chechnya Republic from 24.12.2007 №165. On approval of the lists of rare and endangered plant and animal species listed in the Red Book of the Chechnya Republic, and lists of plant and animal species that need special attention to their condition in the natural environment of the Chechnya Republic. Available online at http://oopt. aari.ru/rbdata/1759/anim.

Regulation. 2010. Regulation of government of Kamchatka Territory from 11.01.2010 №3-ח. On approval of the Lists of rare and endangered objects of the animals and plants listed in the Red Book of Kamchatka Territory. Available online at http://oopt.aari.ru/rbdata/76/anim.

Saveljev A., Strelnikov D., Ekonomov A., Kozlov Yu. \& Glazov D. In press. [Game animals in the project "Atlas of Russian mammals": goals, first results and difficulties] // The Herald of Game Management. Vol.16. No.1. [in Russian with English summary]

Savoure-Soubelet A., Ridoux V., Van Canneyt O., Charrassin J.-B., Aulagnier S. \& Haffner P. 2018. Atlas des Mammifères Sauvages de France: Vol.1: Les Mammifères Marins de France. Paris: French National Museum Natural History. 496 p. 